
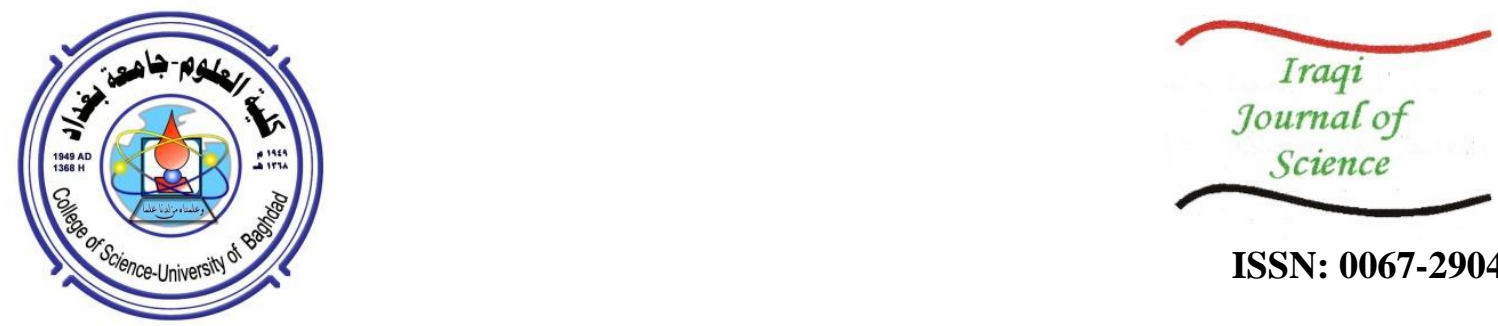

ISSN: 0067-2904

\title{
Spectroscopic Analysis of Clove Plasma Parameters Using Optical Emission Spectroscopy
}

\author{
Neean F. Majeed, Maysaa R. Naeemah, Alyaa H. Ali, Sabah N. Mazhir* \\ Department of Physics, College of Science for Women, University of Baghdad
}

Received: 17/8/2020 Accepted: 25/12/2020

\begin{abstract}
:
In the current study, the emission spectra generated from clove were measured under normal atmospheric pressure with different laser energies. Clove is used as a source of essential oil in herbal medicine, in particular as a dynamic analgesic oil in dental and other diseases. For aromatherapy, Antiseptic, antiviral, and antimicrobial agents are also packaged with cloves. Compounds that reduce inflammation tend to battle sore throats, cold, and cough as they display so many advantages. The measured spectrum reveals distinctive lines of clove's chemical elements. X-ray fluorescent (XRF) and atomic absorption spectrometry (AAS) were used to measure the spectrum generated or absorbed by detecting the presence of various elements and their ratios in the cloves, for different energy the electron temperature varies between 0.043 and $0.073 \mathrm{eV}$ and the number of electron varied between 2.074 and 2.287) $\times 10^{14} \mathrm{~cm}^{-3}$ for clove.
\end{abstract}

Keyword: Atomic absorption, Clove, Plasma Parameters, LIBS, XRF.

\section{التحليل الطيفي لمعلمات بلازما القرنفل باستخدام مطياف الانبعاث الطيفي \\ نيان فربد مجيد، ميساء رابع نعيمة، علياء حسين علي، صباح نوري مزهر

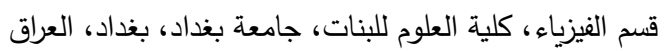

الخلاصة

تم في هذه الدراسة قياس أطياف الانبعاث المتولدة من القرنفل تحت ضغط جوي عادي باستخدام طاقات

ليزر مختلفة. يستخدم القرنفل كزيت أساسي في طب الأعشاب، ويستخدم (كمسكن) على وجه الخصوص الأن

لحالات الطوارئ من وجع الأسنان وغيرها من الاضطرابات، يستخدم الزيت الأساسي لأغراض العلاج بالروائح

العطرية. يحتوي القرنفل على عناصر مختلفة بما في ذلك المطهرات ومضادات الفيروسات ومضادات

الميكروبات. حيث تساعد المركبات المضادة للالتهابات في علاج التهاب الحلق والبرد والسعال لأن لها العديد

من الفوائد، كما تم دراسة المعلمات باستخدام مطيافية القرنفل والميزات الأخرى باستخدام محلات فلات الأشعة

السينية الفلورية (XRF) مطياف الامتصاص الذري (AAS) حيث يظهر الطيف المقاس خطوطًا أو نقاطًا

مميزة من القرنفل العناصر الكيميائية في القرنفل، وتم الكثف عن وجود عناصر وبنسب مختلفة في عينة

القرنفل عن طريق قياس الأطياف المنبعثة أو الممتصة. كنلك حسبت درنة درجة حراة الالكترون وتراوحت بين

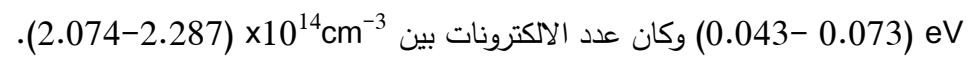

\section{INTRODUCTION}

Laser induced breakdown spectroscopy (LIBS) is an analytical method established on the emission of electromagnetic radiation that produced after excitation of ions, molecules, or atoms existent in the sample test. Typically, that technique is use several kinds of energy source to raise the types present in

*Email: sabahnm_phys@csw.uobaghdad.edu.iq 
the model to levels energy higher from where they decay, producing distinguishing radiation that is collected, sent to a wavelength recorder, and used to identify the nature of the sample, that can be a solid, gas, or liquid [1]. Most of the targeted LIBS samples are solids. In this method, a pulse laser with enough energy, i.e. above the material breakdown threshold, is utilized to produce a plasma and overhead the surface area of the sample making an interaction region. The excited plasma enlarges outside this region, cools down as it interacts with the environment, and releases radiation. This radiation can be collected to a spectrometer, where it is dispersed. The characteristics of spectrum results are documented on a laptop and usually analyzed by using different methods depending on the type of study [2,3]. Because of its experimental plainness, LIBS has reached its high degree of interest, particularly in the fields of agricultural science, medical science, environmental science, and biology. It has become a powerful and very accurate elemental analysis instrument as compared to the conventional standard techniques. It provides a practical, fast, and flexible elemental measurement of the sample structure, with the added benefit of less heavy sample preparation need [4]. The plasma is commonly produced by concentrating a pulsed laser (Nd:YAG) at a wavelength of $1064 \mathrm{~nm}$ on samples LIBS. The concentrations of various elements of environmental significance can be measured by utilizing this technology, for example iron, chromium, cadmium, magnesium, titanium, manganese, phosphorus, barium, copper, calcium, zinc, etc. Some information, such as the initial formation of the material, can be obtained from the plasma spectrum generated. Emission lines' characteristics can supply information about plasma temperature $\left(\mathrm{T}_{\mathrm{e}}\right)$ and electron density (ne) $[5,6,7]$. The method utilized in the laboratory experiments is the Boltzmann plot method, which is widely utilized for spectral measurements. It depends on measuring the relative density for one line of the same element. Nevertheless, to apply the Boltzmann method for the measurement of electron temperature, the level of excitement must be below the local thermal equilibrium (LTE) stipulation. These features allow to use the traditional Boltzmann plot method to calculate $\left(\mathrm{T}_{\mathrm{e}}\right)$ using the following equation $[8,9]$

where

$$
\ln \left(\frac{\lambda_{\mathrm{ji}} \mathrm{I}_{\mathrm{ji}}}{h c A_{j i} g_{j i}}\right)=\frac{-1}{k T}\left(E_{j}\right)+\ln \left(\frac{N}{U(T)}\right)
$$

$\lambda_{\mathrm{ji}}$ is wavelength,

$\mathrm{I}_{\mathrm{ji}}$ is the intensity

$\mathrm{g}_{\mathrm{i}}$ is statistical weight

$\mathrm{A}_{\mathrm{ji}}$ is transition probability for spontaneous emission from the level $\mathrm{i}$ to the lower level $\mathrm{j}$

$E_{j}$ is excitation energy $(\mathrm{eV})$

$\mathrm{k}$ is Boltzmann constant

$\mathrm{N}$ is state population densities

The electron number density was calculated by using Stark broadening method as [5]:

$$
n_{e}=\left(\frac{\Delta \lambda}{2 w_{s}}\right) N_{r}
$$

$\mathrm{n}_{\mathrm{e}}$ : Electron number density, $\omega$ theoretical line full width Stark broadening parameter calculated at the same reference electron density $\mathrm{N}_{\mathrm{r}} \sim 10^{17} \mathrm{~cm}^{-3}[10,11]$.

Clove is a plant grown in some parts of South America and Asia. Numerous people commonly utilize the dried oils, leaves, stems and flower buds for medicinal applications. It is most usually applied to the gums for toothache [12]. Clove is also used in foods as a flavor. In manufacturing, clove is used in soaps, toothpaste, perfumes, cosmetics, and cigarettes. The eugenol is a chemical composite that clove oil contains and acts as an antibacterial agent and anesthetic. Clove oil is considered as antiinflammatory and antifungal, which may help to fight infections and decrease pain. Clove has several additional advantages, exerting anticancer, antihistamine, and ant mutagenic effects [13].

Atomic absorption spectrometry computes elements' concentrations by an analytical technique. AAS is highly sensitive so that it can compute less than parts per billion of a gram in a sample. AAS makes benefit from the light wavelengths that are absorbed specifically from an element. These coincide to the energies needed to promote electrons from one level of energy to another higher energy level. This technique can sense elements in either solid or liquid states through the use of characteristic wavelengths of electromagnetic radiation from a light source. Single elements will absorb wavelengths differently, and this absorbance is then computed [14].

The portable X-ray fluorescent (XRF) analyzers have the ability to quantify any element, from uranium to magnesium, depending on specific instrument configurations. The electrons are moved 
from their positions in the atomic orbital, releasing energy that is characteristic of a specific element. Then, the detector in the XRF instrument records the release of energy [15].

\section{Materials and Methods}

The emitted spectrum of the clove after they were bombed using Nd: YAG laser of $1064 \mathrm{~nm}$ wavelength and 200 pulse laser, $6 \mathrm{~Hz}$ pulse repetition frequency using with various valuable of energy from 600 to $900 \mathrm{~mJ}$. The laser was placed on a distance of $10 \mathrm{~cm}$ from the sample. The process of the row occurred after the plasma column was produced. The resulting light was collected from the plasma via the optical fibers, which were set at an angle of 45 . The laser cuts off the atoms of matter to generate plasma and produce nanomaterials, as shown in Figure-1.

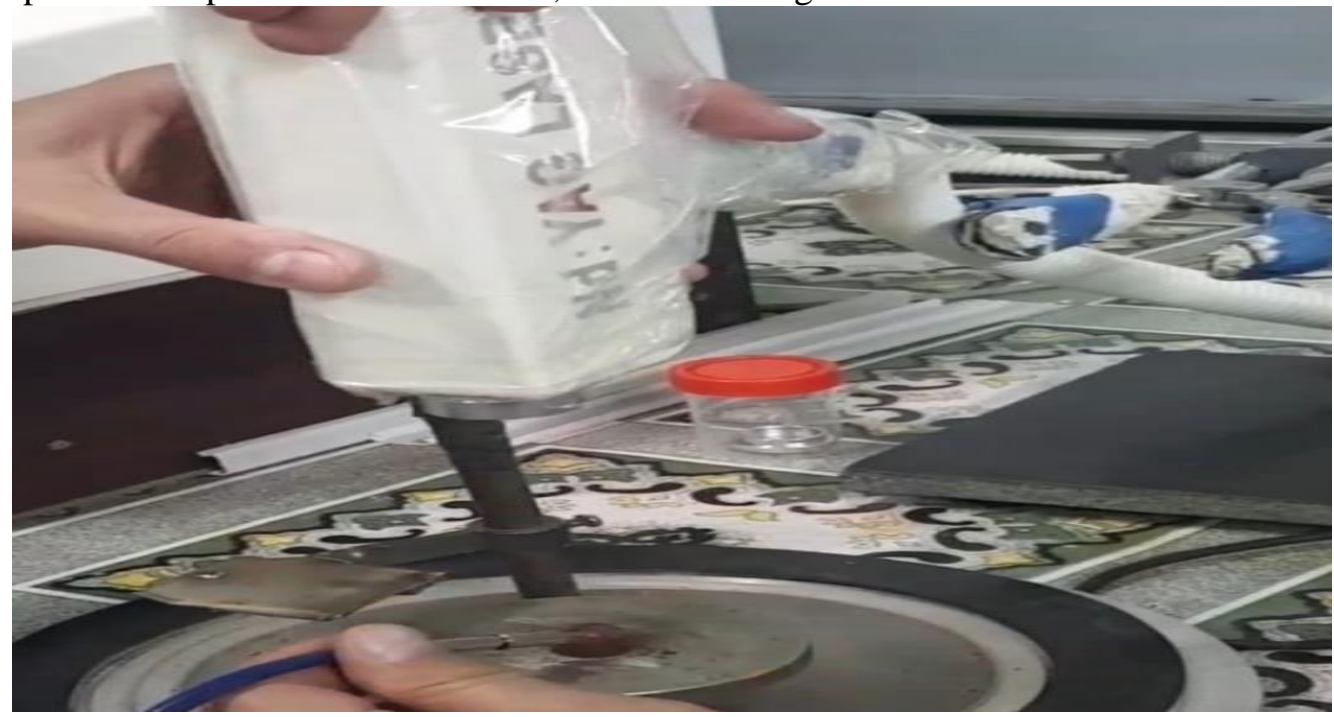

Figure 1-Experimental setup of LIBS

\section{Results and Discussion}

Table-1 presents the results of the XRF analysis of the clove sample. The elements that were detected included manganese, iron, copper, zinc, zirconium, molybdenum, antimony, rubidium, and strontium. Moreover, Table- 2 shows the AAS results of the elements that were detected using this method, which included iron, calcium, zinc, manganese, magnesium, sodium, and potassium.

Table 1-The results of the elements detected in the clove sample using the XRF technology.

\begin{tabular}{|c|c|}
\hline Detected element & Concentration (ppm) \\
\hline $\mathrm{Mn}$ & 227.5 \\
\hline $\mathrm{Fe}$ & 121.5 \\
\hline $\mathrm{Cu}$ & 23 \\
\hline $\mathrm{Zn}$ & 12.7 \\
\hline $\mathrm{Zr}$ & 18.8 \\
\hline $\mathrm{Mo}$ & 10.15 \\
\hline $\mathrm{Sb}$ & 32 \\
\hline $\mathrm{Rb}$ & 37.4 \\
\hline $\mathrm{Sr}$ & 55.3 \\
\hline
\end{tabular}

Table 2- Atomic absorption spectrometry (AAS) in the clove sample

\begin{tabular}{|c|c|}
\hline Detected element & Concentration (percent) \\
\hline $\mathrm{Fe}$ & $0.0285 \%$ \\
\hline $\mathrm{Ca}$ & $0.8596 \%$ \\
\hline $\mathrm{Zn}$ & $0.1796 \%$ \\
\hline $\mathrm{Mn}$ & $0.0698 \%$ \\
\hline $\mathrm{Mg}$ & $0.3783 \%$ \\
\hline $\mathrm{Na}$ & $2.093 \%$ \\
\hline $\mathrm{K}$ & $1.337 \%$ \\
\hline
\end{tabular}


The emission spectra for clove are shows in Figure-2, where the plasma was produced in air at different laser energies $(600,700,800$ and $900 \mathrm{~mJ})$. The spectra of optical emission of clove's plasma were recorded using optical emission spectroscopy (OES) in the spectral range of 320-850, which belongs to neutral and singly ionized elements, as a function of wavelength. Figure-3 demonstrates the Lorentzian fitting curve.

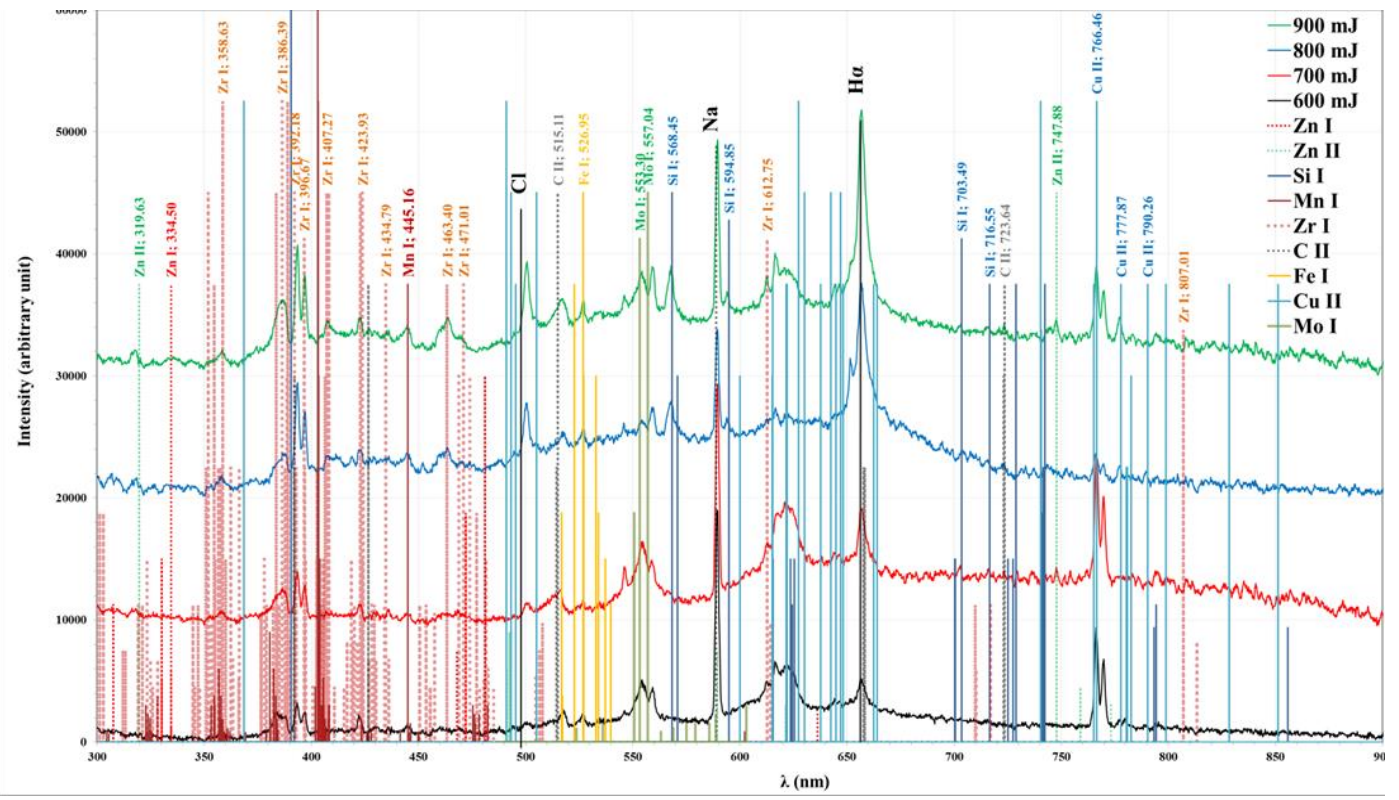

Figure 2-Optical emission spectra for clove plasma produced with different energy values of lase r.

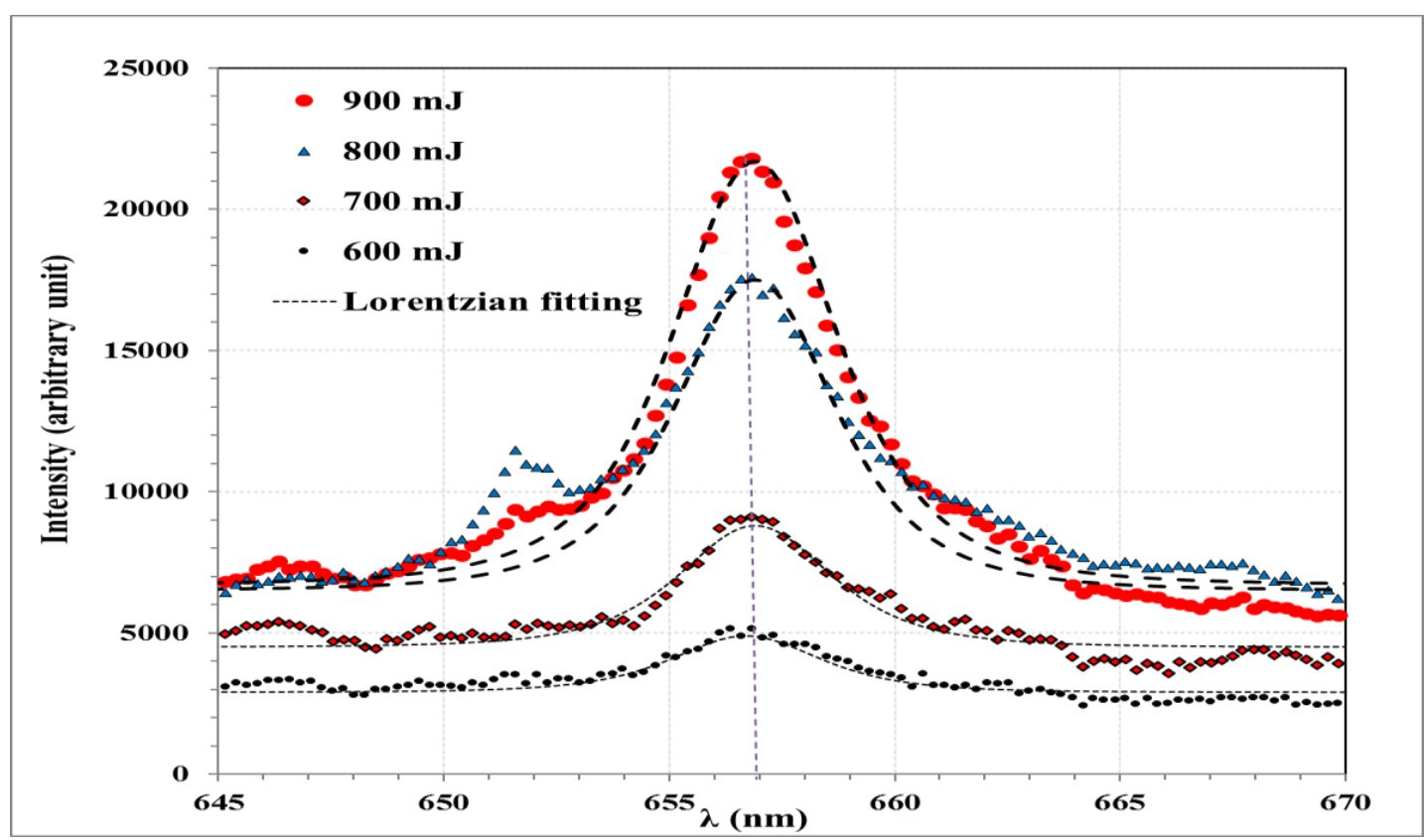

Figure 3-The Lorentzian fitting with a wave length from 645 to $670 \mathrm{~nm}$

Figure-4 shows Boltzmann plots of clove with different energies of laser. The calculated values, using Boltzmann plot equation from the line strength ratio, illustrate that the temperature of electron $\left(\mathrm{T}_{\mathrm{e}}\right)$ and the density of electron (ne) are increasing with increasing laser energy. The National Institute of Standards and Technology (NIST) data site represented by taken two spectrum lines [16] 

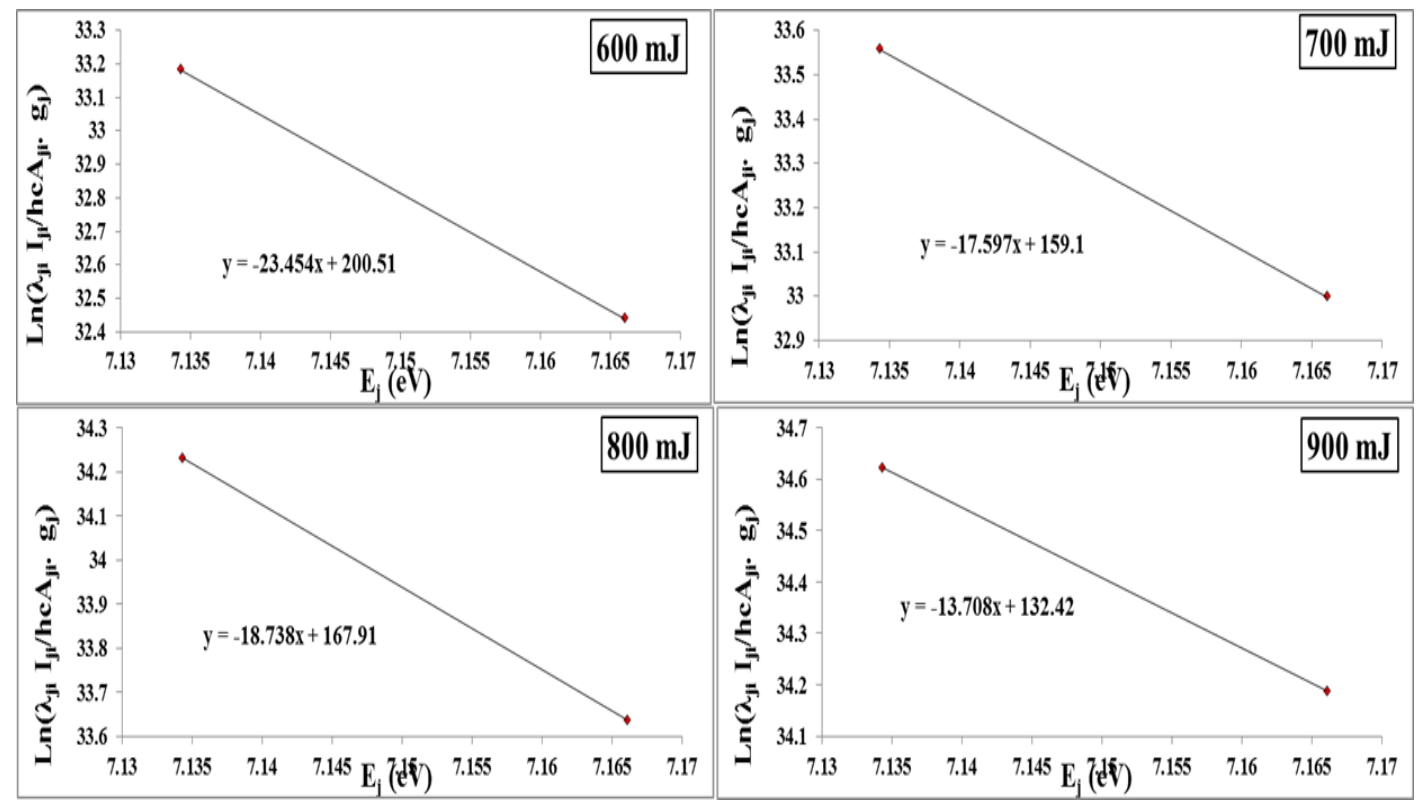

Figure 4-Boltzmann plots of clove with different laser energies

The line graph in Figure-5 illustrates the influence of the change of different energy values of the laser on the two parameters of the Electron temperature $\left(T_{e}\right)$ and the Electron number density $\left(n_{e}\right)$. is the results show that the $T_{e}$ and $n_{e}$ values increase gradually with the rise of energy. Table- 3 shows plasma parameters for clove at different energy values $(600,700,800$ and $900 \mathrm{~mJ})$. We can see that the values of $T_{e}, F W H M(n m)$, and electron number density $\left(n_{e}\right)$ increase as the laser energy increases. The increase in the intensity of the emission lines is primarily dependent on the laser maximum energy. The increase in laser peak energy results in an increased spectral line intensity, as the mass ablation rate of the target is increased. Moreover, the increase in plasma absorption depends primarily on the increase of laser energy, which contributes to an increase in ablation and the number of excited atoms. As a consequence, the intensities of the spectral line exceed plasma speeds.

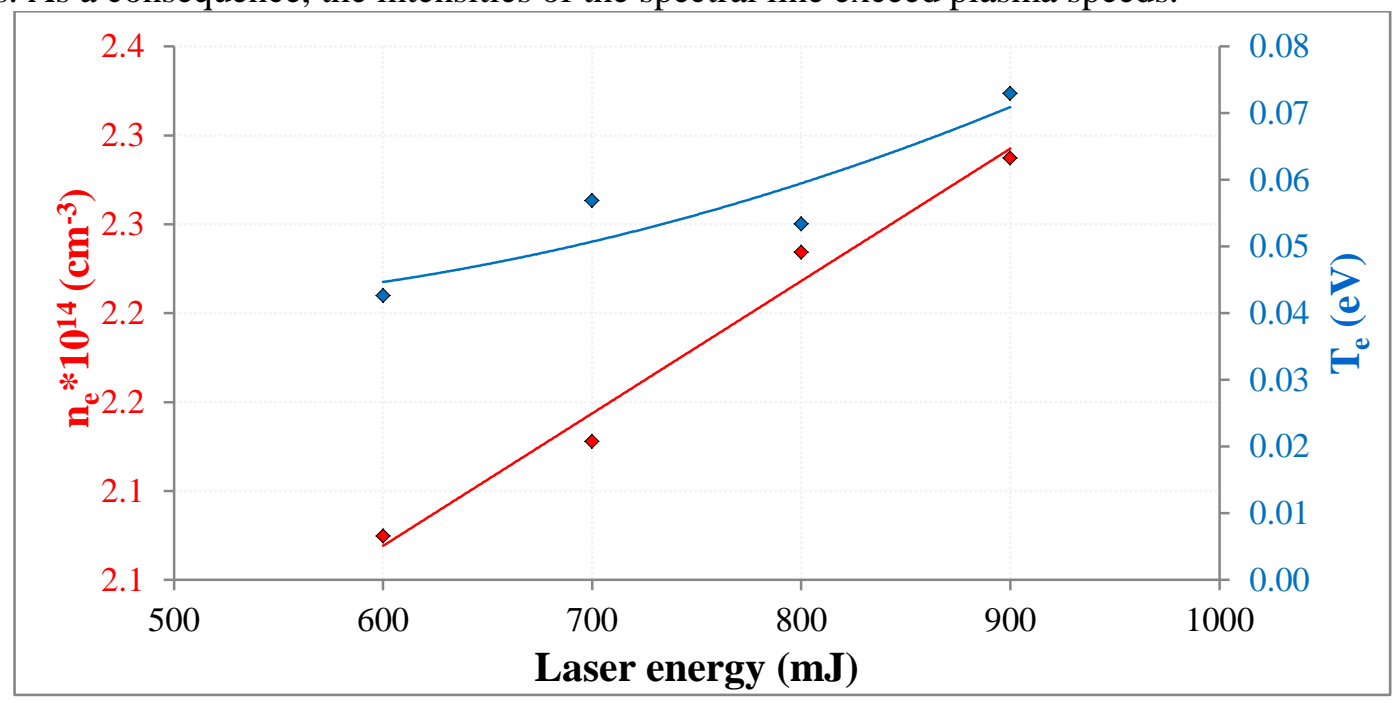

Figure 5-The variation of $\left(\mathrm{T}_{\mathrm{e}}\right)$ and $\left(\mathrm{n}_{\mathrm{e}}\right)$ versus the laser energy of clove target

Table 3-plasma parameter for clove

\begin{tabular}{|c|c|c|c|}
\hline $\mathbf{E}(\mathbf{m} \mathbf{J})$ & $\mathbf{T}_{\mathbf{e}}(\mathbf{e V})$ & $\mathbf{F W H M}(\mathbf{n m})$ & $\mathbf{n}_{\mathrm{e}^{*}} \mathbf{1 0}^{\mathbf{1 4}}\left(\mathbf{c m}^{\mathbf{- 3}}\right)$ \\
\hline 600 & 0.043 & 3.900 & 2.074 \\
\hline 700 & 0.057 & 4.000 & 2.128 \\
\hline 800 & 0.053 & 4.200 & 2.234 \\
\hline 900 & 0.073 & 4.300 & 2.287 \\
\hline
\end{tabular}




\section{Conclusions}

The intensity of the emission spectrum lines of the generated cold plasma depends highly on operating conditions. It was demonstrated that the increase in the energy leads to an increase in the intensity of emission. The XRF findings revealed that cloves contain nine elements, although the results obtained from the AAS analysis showed only seven elements. This is because AAS is a continuum, where the wavelength depends on the product of the absorption of the light energy by the free atoms. The absorbed radiation energy is formed in the form of very narrow absorption lines in the visible and ultraviolet regions of the electromagnetic spectrum. This energy excites the valence electrons in the shells of the atom. While XRF depends on the elements which are displaced from their atomic orbital positions, where energy is released and detected in the XRF equipment and the elements can be known by their energies.

\section{References}

1. Pasquini C. Cortez J. Silva L M C. Gonzaga F B. 2007. Laser Induced Breakdown Spectroscopy. J. Braz. Chem. Soc. 18(3):463-512. https://dx.doi.org/10.1590/S0103-50532007000300002.

2. Gaudiuso R. Melikechi N. Abdel-Salam Z A. Harith M A. Palleschi V. Rose V M. Bussere B. 2019. Laser-induced breakdown spectroscopy for human and animal health: A review, Spectrochimica Acta Part B: Atomic Spectroscopy, 152: 123-148. https://doi.org/10.1016 /j.sab. 2018.11 .006

3. Mazhir S. N. 2018. Spectroscopic study of $\left(\mathrm{TiO}_{2}\right)_{1-\mathrm{x}}(\mathrm{CuO})_{\mathrm{x}}$ plasma generated Nd:YAG. Laser, ARPN Journal of Engineering and Applied Sciences, 13(3): 864-869.

4. Singh, V.K., Sharma, J., Pathak, A.K. 2018. Laser-induced breakdown spectroscopy (LIBS): a novel technology for identifying microbes causing infectious diseases. Biophys Rev, 10: 12211239 (2018). https://doi.org/10.1007/s12551-018-0465-9

5. Hussein W. S, Ahmed A F., 2019. Study of parameters of cadmium sulfide plasma produced by LIBS technique by using optical emission spectroscopy, 17(42): 103-107.

6. Khalaf M A. Ahmed B M. Aadim K A. 2020. Spectroscopic Analysis of $\mathrm{CdO}_{1-\mathrm{x}}: \mathrm{Sn}_{\mathrm{X}}$ Plasma Produced by Nd:YAG Laser, Iraqi Journal of Science, 61(7): 1665-1671. DOI: 10.24996 /ijs. 2020.61.7.15

7. Aadim K. A, Mazhir S N, Abdalameer N K., Ali A. H. 2020. Influence of gas flow rate on plasma parameters produced by plasma jet and its spectroscopic diagnosis using OES technique. IOP. Conf. Ser.: Mater. Sci. Eng. 987, 012020. https://doi:10.1088/1757-899X/987/1/012020.

8. Noriyasu O. Abdur Razzak M. Ukai H. Shuichi Takamura S. Uesugi Y. 2006. Validity of Electron Temperature Measurement by Using Boltzmann Plot Method in Radio Frequency Inductive Discharge in the Atmospheric Pressure Range, Plasma and Fusion Research: Regular Articles, 1 (028):1-9.

9. Ismail M A. Imam H, Elhassan A, Youniss W T, M.A. Harith, 2004. LIBS limit of detection and plasma parameters of some elements in two different metallic matrices Journal of Analytical Atomic Spectrometry, 19(4): 489-495.

10. Muryoush, A. Q., Ali, A. H. and Al-Ahmed, H. 2019. Effect of cold plasma on histological compositions of the rabbit's fracture bone tissue. Iraqi Journal of Science, 60(9):1997-2002. https://doi.org/10.24996/ijs.2019.60.9.12.

11. Hammad R. H. Abbas Q A. and Rauuf A. 2017. Effect of Gas Flow Rate on The Electron Temperature, Electron Density and Gas temperature for Atmospheric Microwave Plasma Jet. International Journal of Engineering and Technology, 5(6):3819-3822

12. Jiang Q, Wu Y, Zhang H, Wu Y. Liu P. Yao J. 2017. Development of essential oils as skin permeation enhancers: penetration enhancement effect and mechanism of action. Pharmaceutical Biol.; 55(1):592-1600. https://dx.doi.org/10.1080\%2F13880209.2017.1312464.

13. Ibrahim I M, Elsaie M L. Almohsen A M. Mohey-Eddin M H. 2017. Effectiveness of topical clove oil on symptomatic treatment of chronic pruritus. J Cosmet Dermatol, 16:508-11

14. Kaur H, 2010. Instrumental methods of chemical analysis, 6th Edition, Prakashan, India.

15. Shackley S M. 2011. X-Ray Fluorescence Spectrometry (XRF) in Geoarchaeology, Springer New York Dordrecht Heildelberg, London.

16. National Institute of Standards and Technology (NIST). Atomic spectra database, 5, 2017. 